\title{
6. SEDIMENTATION RATES: TOWARD A GRAPE DENSITY STRATIGRAPHY FOR LEG 138 CARBONATE SECTIONS ${ }^{1}$
}

\author{
N. J. Shackleton ${ }^{2}$ and Shipboard Scientific Party ${ }^{3}$
}

\section{INTRODUCTION}

The use of continuous GRAPE density measurements for correlating different holes at the same site is based on the presumption that the sedimentary sequence cored does contain real and detectable density variations. This assumption is amply justified because the chief source of density variations in most Leg 138 cores is changing carbonate content; it is equally plausible that GRAPE density records might be as useful for correlation among sites as carbonate content (Mayer, 1991; Vincent, 1981). The sites on the western transect of Leg 138 are spaced closely enough that one might expect to correlate them with considerable precision. As a first step, a series of GRAPE "events" were selected to provide accurate tie-lines among the sites at intervals of about 0.5 m.y. This provided the basis for constructing sedimentation rate histories for all sites in a completely consistent manner. Ultimately, one should be able to carry this exercise to a much finer temporal resolution.

Here, we derive a new set of sedimentation rates for Leg 138 sites on the basis of three modifications to the estimates presented in individual site chapters. First, a GRAPE density stratigraphy was developed by identifying an identical set of control points for estimating sedimentation rates in all the sites. Second, the best age was estimated for each event so that the time scale used was identical for all sites. Third, we adjusted the thickness of composite depth sections on the basis of the mean relationship between mcd and mbsf scales in the composite advanced hydraulic piston (APC) sections and the composite extended-core barrel (XCB) sections (see Hagelberg et al., this volume). Then, we adjusted this further to the log depths in those parts of the sections for which downhole density logs were available. Note that these last two functions were conducted solely to obtain the best estimate of the true thicknesses of the packages of sediment between the tie-lines for estimating sedimentation rates; our intention was not to create two more depth scales.

Our procedure was based on the availability of a composite depth section for each site, together with a considerable amount of biostratigraphical data. With this information, the GRAPE records were compared over successively older time intervals, and a general picture of temporal variations was built up. In most sites, the GRAPE record contained (1) some extremes of high or low density, (2) some intervals of repetitive cyclic changes, (3) some intervals of low amplitude, and (4) a characterless record. To facilitate correlation, we initially tried to select GRAPE density "events" with a distinctive character. However, the character of the GRAPE density records changes considerably through the succession of sites, and it is certainly not possible to carry the identification of a particular event through all the Leg 138 sites solely on the basis of the magnitude or shape of the event. Thus, the identification of a particular event was based, first, on the magnetostratigraphy and biostratigraphy and, second, on the hypothesis that

${ }^{1}$ Mayer, L., Pisias, N., Janecek, T., et al., 1992. Proc. ODP, Init. Repts., 138: College Station, TX (Ocean Drilling Program).

${ }^{2}$ The Godwin Laboratory, Cambridge University, Free School Lane, Cambridge CB2 3RS, U.K.

${ }^{3}$ Shipboard Scientific Party is as given in list of participants preceding the contents. a common component occurs in variability that is sufficient, so that identification of a particular event may be used from one site to the next. At present, this hypothesis is untested outside the Pleistocene, although reviews such as that of Vincent (1981) imply that a common element in carbonate stratigraphies can be traced over the whole Pacific Basin. However, in the Pleistocene, the concept of carbonate stratigraphy has been established since the work of Arrhenius (1952). Farrell and Prell (1989) showed how this concept reflects systematic vertical migrations of the calcite compensation depth (CCD) and the lysocline that pervade at least the whole equatorial region of the Pacific Ocean. Thus, it seems inherently likely that our strategy will succeed.

The following section describes each event in an informal manner. Our intention is that a formal structure will be set up that will permit detailed correlation throughout the sections. At this interim stage, the events are denoted alphabetically, and the site in which the event may be regarded as defined is identified.

In this exercise, the prime consideration for selecting GRAPE "events" was that they should be as near as possible to either a magnetic reversal or a well-constrained biostratigraphic datum, so that the time scale applied to the cores through these events should be as nearly as possible consistent with that developed in the individual site chapters. As much as possible, events were selected near magnetic reversals. This is important because in Sites 846 through 853, the density variations probably have been driven by changing carbonate content. This is not true of most of the record of Sites 844 and 845, but on the other hand, the magnetostratigraphy in those sites should enable at least some of the GRAPE tie-lines to be carried accurately into those two sites. However, note that had proximity to magnetic reversals not been a consideration, we would have found it prudent to select (where possible) prominent density maxima for this exercise. Because coring disturbance is much more likely to generate spurious density minima than maxima, maxima in the GRAPE density records are inherently more reliable than minima. It is probably equally true, at least in this region, that spurious density minima are more probable than spurious maxima in the downhole density log, because the low-density, diatom-rich sediments are more likely to cave in at the sides of the hole. For this reason, as well as to avoid reaching false conclusions, we do not plan to use the widespread nomenclature for Pacific carbonate curves by which carbonate minima generally are emphasized, rather than carbonate maxima. Note that in Site 853, where sedimentation rates are low, some of the events have been selected directly from the paleomagnetic record, rather than using GRAPE density records. The depths and assigned ages for events A through $\mathrm{S}$ are presented in Table 1. These events are shown in Figure 1 (back-pocket figure).

Event $\mathrm{A}$ is a distinct density minimum having an age of about 0.46 Ma. This is near the extinctions of Pseudoemiliania lacunosa and of Stylatractus universus. This age is defined at about $15.8 \mathrm{mcd}$ in Site 847. In Site 853 , the selection of a minimum at $1.2 \mathrm{mcd}$ is arbitrary, given such a low sedimentation rate.

Event B is a density maximum that coincides with the Brunhes/ Matuyama reversal $(0.73 \mathrm{Ma})$ and that is typified at $15.3 \mathrm{mcd}$ in Site 851. At sites where the chief density maximum has two minor peaks, event B is the upper of these.

Event $C$ is a density peak immediately above the top of the Olduvai at $33.0 \mathrm{mcd}$ in Site 851 and has an age of about $1.63 \mathrm{Ma}$. This event 
Table 1. GRAPE density events for Sites 846 through 853 .

\begin{tabular}{|c|c|c|c|c|c|c|c|c|c|}
\hline Event & $\begin{array}{l}\text { Age } \\
\text { (Ma) }\end{array}$ & $\begin{array}{l}\text { Site } 846 \\
\text { Depth } \\
\text { (mcd) }\end{array}$ & $\begin{array}{l}\text { Site } 847 \\
\text { Depth } \\
\text { (mcd) }\end{array}$ & $\begin{array}{c}\text { Site } 848 \\
\text { Depth } \\
\text { (mcd) }\end{array}$ & $\begin{array}{c}\text { Site } 8.49 \\
\text { Depth } \\
\text { (mcd) }\end{array}$ & $\begin{array}{l}\text { Site 850 } \\
\text { Depth } \\
\text { (mcd) }\end{array}$ & $\begin{array}{l}\text { Site 851 } \\
\text { Depth } \\
\text { (mcd) }\end{array}$ & $\begin{array}{c}\text { Site } 852 \\
\text { Depth } \\
\text { (mcd) }\end{array}$ & $\begin{array}{l}\text { Site } 853 \\
\text { Depth } \\
\text { (mcd) }\end{array}$ \\
\hline Top & 0 & 0 & 0 & 0 & 0 & 0 & 0 & 0 & 0 \\
\hline$A^{O P}$ & 0.47 & 18.7 & 15.8 & 7.1 & 12.5 & 8.4 & 9.7 & 4.2 & 1.2 \\
\hline B & 0.73 & 28.6 & 24.5 & 12.7 & 19.3 & 16.0 & 15,3 & 9.0 & 3.6 \\
\hline C & 1.63 & 60.8 & 56.3 & 24.8 & 49.1 & 33.4 & 33,0 & 21.0 & 7.5 \\
\hline D & 2.40 & 97.8 & 84.3 & 31.1 & 71.6 & 51.2 & 47.5 & 29.0 & 11.8 \\
\hline $\mathrm{E}$ & 2.99 & 128.2 & 101.5 & 34.2 & 86.9 & 64.7 & 59.2 & 36.4 & 15.7 \\
\hline $\mathrm{F}$ & 3.44 & 145.2 & 117.4 & 36.6 & 101.5 & 76.2 & 69.1 & 41.7 & 18.9 \\
\hline G & 4.00 & 164.4 & 135.0 & 39.6 & 120.5 & 89.9 & 80.2 & 48.2 & 23.5 \\
\hline $\mathrm{H}$ & 4.45 & 189.8 & 165.0 & 45.9 & 148.1 & 112.0 & 93.8 & 55.5 & 28.2 \\
\hline i & 4.95 & 218.0 & 196.2 & 52.9 & 185.5 & 141.0 & 114.5 & 65.8 & 34.1 \\
\hline $\mathrm{j}$ & 5.48 & 250.5 & 204.4 & 63.5 & 225.8 & 175.0 & 140.0 & 75.0 & 41.0 \\
\hline K & 6.00 & 261.0 & 217.2 & 72.5 & 255.9 & 203.5 & 159.5 & 83.2 & 47.4 \\
\hline $\mathrm{i}$ & 6.40 & & 238.2 & 76.0 & 274.5 & 226.0 & 180.8 & 89.8 & 51.8 \\
\hline M & 6.73 & 297.2 & & 81.3 & 303.3 & 258.0 & 207.5 & 95.8 & 57.6 \\
\hline $\mathrm{N}$ & 7.40 & 310.6 & & 85,2 & 314.7 & 272.7 & 227.0 & 106.2 & 68.9 \\
\hline 0 & 8.00 & 313.9 & & 88.5 & 326.8 & 289.0 & 243.9 & 115.5 & 72.4 \\
\hline P & 8.41 & 325.5 & & 91.0 & 337.2 & 304.5 & 265.0 & 117.1 & \\
\hline Q & 8.92 & 3358 & & 94.4 & 348.5 & 320.1 & 279.6 & 119.6 & \\
\hline$R$ & 9.40 & 338.3 & & 96.9 & 354.0 & 336.5 & 293.4 & 122.4 & \\
\hline $\mathrm{S}$ & $10.06)$ & 342.7 & & & 364.5 & 363.5 & 324.7 & & \\
\hline Salt & 9.90 & & & & & & & 127.5 & \\
\hline
\end{tabular}

is less than 0.1 m.y. older than the first appearance of Gephyrocapsa oceanica and is near the extinction of Pterocanium prismatium.

Event D is a density minimum that is just above the Gauss/ Matuyama boundary and is associated with the upper limit of Discoaster surculus, with an age of about 2.40 Ma. In Site 846, where it is defined, the event is found at $97.8 \mathrm{mcd}$.

Event $\mathrm{E}$ is a short, sharp density maximum at the base of the Kaena Subchron (2.99 Ma). It is clearly expressed at Sites 849,850 , and 851 . In Site 847 , this event is found at $101.5 \mathrm{mcd}$, within the determined limits of the top of Rhizosolenia praebergonii. In Site 848, the event is detectable only with the aid of magnetostratigraphy at 34.2 mcd; similarly, in Site 852 at 36.4 mcd, where it merges with the peak or peaks above, and in Site 853, where the base of the Kaena Subchron is found at $15.74 \mathrm{mcd}$.

Event $\mathrm{F}$ is a sharp density maximum between two low extremes, just below the Gilbert/Gauss boundary and just above the extinction of Reticulofenestra pseudoumbilicus and near the upper limit of Sphenolithus abies, with an age of $3.44 \mathrm{Ma}$. At Site 851 , this event is clearly defined with respect to magnetostratigraphy at $69.1 \mathrm{mcd}$.

Event $\mathrm{G}$ is a sharp density minimum at or just below the base of the Cochiti Subchron. This event is defined at about $80.2 \mathrm{mcd}$ in Site 851 and has an age of $4.0 \mathrm{Ma}$. It is generally within or just below the range of the upper limit of Didymocyrtis penultima. In Site 847, the event is found at $135.0 \mathrm{mcd}$, which is the upper of two similar and closely spaced density minima. In Site 849 , the event is found at $120.5 \mathrm{mcd}$, just below the upper limit of $D$. penultima.

Event $\mathrm{H}$ is a marked density maximum near the base of the Sidujfall Subchron and has an age of $4.45 \mathrm{Ma}$. It is defined at 148.1 mcd in Site 849, a few meters below an extreme density minimum. This event is in a similar relationship at Site 846 at $189.8 \mathrm{mcd}$. In Site 847, it was clearly recovered at 165 mcd in the bottom of Core 138-847A-16H. In Site 848, this event is found at $45.9 \mathrm{mcd}$ (in Holes $848 \mathrm{~B}$ and $848 \mathrm{C}$ only), within the Sidjufall Subchron and just below the upper limit of Nitzschia cylindrica.

Event $\mathrm{I}$ is a prominent density maximum having an age of about 4.95 Ma, often with an irregular sawtooth shape following a density minimum and terminated by a rapid decrease to low density (seen at $218 \mathrm{mcd}$ in Site 846), just above the last appearance of Discoaster quinqueramus and just below the last appearance of Solenosphaera omnitubus. In Site 847, the event may be represented by the peak at $196.2 \mathrm{mcd}$, although note that continuity is not unambiguously demonstrated between Cores 138-847B-18X and 138-847C-19X at 193 to 194 mcd. It may be that, in fact, the maximum at $193 \mathrm{mcd}$ in Hole $847 \mathrm{C}$ is event $\mathrm{I}$ and that the density minimum above this event was not recovered in either hole. At Site 848 , event I may be represented in the density peak at about $52.9 \mathrm{mcd}$, although we are not certain. This event exemplifies the difficulty when carrying GRAPE events across a very wide range of sedimentation rates; the character of the event (as observed at Site 846) is not preserved in the sites that have more normal sedimentation rates. Interpolation between the base of the Thvera Subchron (4.77 Ma) and the top of C3A-n1 (5.35 Ma) yields an age of $5.01 \mathrm{Ma}$ at Site 852 . However, event I is generally slightly younger than the upper limit of $D$. quinqueramus, to which we assigned an age of 4.98 Ma in Leg 138 research (see "Introduction" chapter, this volume). To remain consistent with this value, here Event I has been assigned an age of $4.95 \mathrm{Ma}$.

Event $\mathrm{J}$ has an estimated age of $5.48 \mathrm{Ma}$ and is identified in Site 848 as a density peak at $63.5 \mathrm{mcd}$, bracketed by the upper limits of Nitzschia miocenica and N. miocenica var. elongata. In Site 847, the event was identified at $204.4 \mathrm{mcd}$, although if this identification and that of event $I$ are correct, it is possible that a hiatus may be found between the two. In Site 849 , event J can be identified as a clearly defined, broad peak at $225.8 \mathrm{mcd}$; in Site 850 , the peak is extremely broad and has a maximum at about $175.0 \mathrm{mcd}$, within the range of the upper limit of Nitzschia miocenica. In Site 851, the narrow peak at $140 \mathrm{mcd}$ may represent event $\mathrm{J}$, although the peak below is a possible candidate. In Site 852 , the event is at $75.0 \mathrm{mcd}$, above the base of Chron $\mathrm{C} 3 \mathrm{~A}-\mathrm{n} 1$; the interpolated age based on this site is $5.48 \mathrm{Ma}$.

Event $\mathrm{K}$ is a density minimum in or below the range of the lower limit of Thalassiosira miocenica and $T$. convexa with an estimated age of $6.0 \mathrm{Ma}$. It is probably represented by the density minimum at about $72.5 \mathrm{mcd}$ in Site 848 that is just below the observed range of the above diatom species. In Site 849 , where event $\mathrm{K}$ is defined, it is at 255.9 mcd; in Site 850 , the density minimum at about 203.5 mcd probably represents the same event, although this is within the range of $T$. miocenica. The age of event $\mathrm{K}$ was estimated as $6.0 \mathrm{Ma}$ by using the biostratigraphic age control in the sites in which the event was recognized; the ages of the older events were estimated using the same method.

Event $\mathrm{L}$ is a density maximum close to, but usually above, the first appearance of Amaurolithus primus, with an age of about $6.4 \mathrm{Ma}$. In Site 846 , the event was not recovered, because Core $138-846 \mathrm{~A}-26 \mathrm{X}$ was barren, but the event can be tentatively identified in the density $\log$. There, the event is seen as a strong density maximum at $76.0 \mathrm{mcd}$ in Site 848, within the range of the first appearance of A. primus. Event L is clearly represented in Site 849 at 274.5 to $276 \mathrm{mcd}$ (it is probable that the same event is present in the base of Cores 138-849B$26 \mathrm{X}$ and $-849 \mathrm{C}-26 \mathrm{X}$, although the degree of overlap among cores is small, because the event is characterized at Sites 850 (226 mcd) and 851 (at $180.8 \mathrm{mcd}$ ) by a sharp, single density maximum. In Site 852 , the peak is clear at 89.8 mcd, while the correlative depth in Site 853 is probably $51.8 \mathrm{mcd}$. The mean age of this event (estimated using biostratigraphic control in Leg 138 sites) is about 6.4 Ma. In Hole $852 \mathrm{D}$, the interval between 88.9 and $91.5 \mathrm{mcd}$ appears to be normally 
magnetized; if these values are the true bounds of C $3 \mathrm{~A}-\mathrm{n} 3$, the interpolated age of event $\mathrm{L}$ is about $6.42 \mathrm{Ma}$; however, because the magnetic record is not clear, we used the rounded value of $6.4 \mathrm{Ma}$.

Event $\mathrm{M}$ is a density maximum at $303.3 \mathrm{mcd}$ in Site 849 , where it is defined as the lower of two maxima less than $2 \mathrm{~m}$ apart, below the first appearance of Nitzschia miocenica. In Site 848, only a single density peak is present at $81.3 \mathrm{mcd}$, just below the top of Chron C4-n1 $(6.7 \mathrm{Ma})$. In Site 850 , the peak is at $258.0 \mathrm{mcd}$, a few meters below the base of $N$. miocenica, and in Site 851, the event is at 207.5 (note that two density maxima also occur in these two sites). In all these sites, this is the first density peak following the upper limit of Diartus hughesi. In Site 852, the event is probably at $95.8 \mathrm{mcd}$ and in Site 853 , at $57.6 \mathrm{mcd}$; the correlation among the GRAPE density records of Sites 848,852 , and 853 , is excellent; however, in this interval, correlation is not straightforward among these three sites and the remaining sites. In Site 848, the event identified is also a little below the base of $N$. miocenica. The mean age estimated for this event (based on the biostratigraphic age models that have been used in the Leg 138 site chapters) is about $6.9 \mathrm{Ma}$; however, the age assigned on the basis of Sites 848 and 853 using the magnetostratigraphy in these sites is significantly younger, at 6.71 and $6.75 \mathrm{Ma}$, respectively; here, we used $6.73 \mathrm{Ma}$.

Event $\mathrm{N}$ is a density minimum defined in Site 849 at $314.7 \mathrm{mcd}$ and has an age near 7.4 Ma. The event is within the range of the observed base of Nitzschia cylindrica and the top of Thalassiosira yabei. In Site 846, it is probably at about $310.6 \mathrm{mcd}$. In Site 848, the event is at $85.2 \mathrm{mcd}$, near the base of Chron C4-n3. In Site 850 the minimum at $272.7 \mathrm{mcd}$ is not very well developed. It is possible that event $\mathrm{N}$ was missed between two cores, but no unrecovered density minimum is evident in the density $\log$. In Site 851 , it is probably at 227 mcd near the base of Discoaster berggreni. This age is near 7.4 $\mathrm{Ma}$, if it has been correctly correlated to Sites 848 and 853 , which record the event within an interval of normal magnetization that has been interpreted as Chron C4-n3.

Event $\mathrm{O}$ is a density peak at about $8 \mathrm{Ma}$, defined in Site 849 at $326.8 \mathrm{mcd}$, where it is near the upper limit of $B$. miralestensis and the transition of Diartus pettersoni to D. hughesi. In Sites 850 and 851, the event is associated with the same radiolarian events. In Site 848, it is located at $88.5 \mathrm{mcd}$, within Chron C4A-n1. The mean age of event $\mathrm{O}$ is about $8.0 \mathrm{Ma}$, based on its position in the upper part of Chron C4A-n1.

Event $\mathrm{P}$ is a density minimum flanked by two maxima at 337.2 mod in Site 849, near the upper limit of Stichocorys wolffii in that site. In Site 848, it is at $91 \mathrm{mcd}$, at the top of Chron C4A-n2 (8.41 Ma), and in Site 852, it is clearly seen at $117.1 \mathrm{mcd}$, also at the top of Chron C4A-n2.

Event $\mathrm{Q}$ is a density maximum at the top of Chron C5 (8.92 Ma). In Site 849 , it is at $348.5 \mathrm{mcd}$, between two prominent density minima
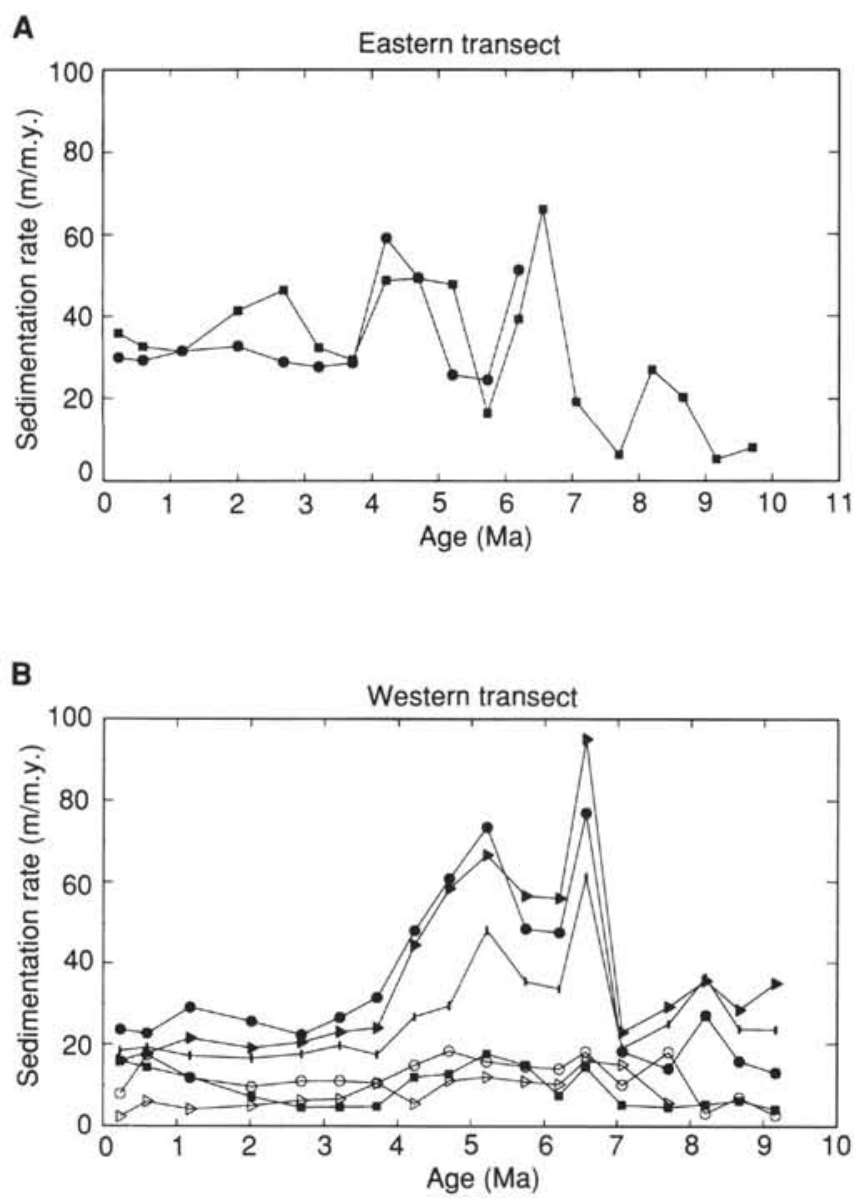

Figure 2. Sedimentation rates from Table 4. For each site, the sedimentation rate has been plotted at the mid-point of the time interval over which it was estimated. A. Sites 846 (solid squares) and 847 (solid circles). B. Sites 848 through 852 . Site $848=$ solid squares; Site $849=$ solid circles; Site $850=$ solid triangles; Site 851 = tick marks; Site 852 = open circles; and Site 853 = open triangles.

at the lower end of the region of low density that is associated with the upper limit of D. hustedti and Discoaster hamatus.

Event $\mathrm{R}$ is defined in Site 849 at about $354 \mathrm{mcd}$ and is at the point of highest density in this part of the section, at about 9.4 Ma. The likely correlative in Site 846 is at $338.3 \mathrm{mcd}$. This correlative is recognized at $97.0 \mathrm{mcd}$ in Site 848 as the highest of three density maxima in mid-C5-n1.

Table 2. Sedimentation rates based on data in Table 1.

\begin{tabular}{|c|c|c|c|c|c|c|c|c|}
\hline $\begin{array}{c}\text { Mean } \\
\text { age }(\mathrm{Ma})\end{array}$ & $\begin{array}{c}\text { Site } 846 \\
\text { Sed. rate } \\
(\mathrm{mcd} / \mathrm{m} . \mathrm{y} .)\end{array}$ & $\begin{array}{c}\text { Site } 847 \\
\text { Sed. rate } \\
(\mathrm{mcd} / \mathrm{m} . \mathrm{y} .)\end{array}$ & $\begin{array}{c}\text { Site } 848 \\
\text { Sed. rate } \\
(\mathrm{mcd} / \mathrm{m} . \mathrm{y} .)\end{array}$ & $\begin{array}{c}\text { Site } 849 \\
\text { Sed. rate } \\
(\mathrm{mcd} / \mathrm{m} . \mathrm{y} .)\end{array}$ & $\begin{array}{c}\text { Site } 850 \\
\text { Sed. rate } \\
(\mathrm{mcd} / \mathrm{m} . \mathrm{y} .)\end{array}$ & $\begin{array}{c}\text { Site } 851 \\
\text { Sed. rate } \\
(\mathrm{mcd} / \mathrm{m} . \mathrm{y} .)\end{array}$ & $\begin{array}{c}\text { Site } 852 \\
\text { Sed. rate } \\
(\mathrm{mcd} / \mathrm{m} . \mathrm{y} .)\end{array}$ & $\begin{array}{c}\text { Site } 853 \\
\text { Sed. rate } \\
(\mathrm{mcd} / \mathrm{m} . \mathrm{y} .)\end{array}$ \\
\hline $\begin{array}{l}0.23 \\
0.60 \\
1.18 \\
2.02 \\
2.70 \\
3.22 \\
3.72 \\
4.23 \\
4.70 \\
5.22 \\
5.74 \\
6.20 \\
6.57 \\
7.07 \\
7.70 \\
8.21 \\
8.67 \\
9.16\end{array}$ & $\begin{array}{l}40.1 \\
37.5 \\
35.8 \\
48.1 \\
51.5 \\
37.8 \\
34.3 \\
56.4 \\
56.4 \\
61.3 \\
20.2\end{array}$ & $\begin{array}{l}33.9 \\
33.0 \\
35.3 \\
36.3 \\
29.2 \\
35.3 \\
31.4 \\
66.7 \\
62.4 \\
15.5 \\
24.6 \\
52.5\end{array}$ & $\begin{array}{r}15.2 \\
21.2 \\
13.4 \\
8.2 \\
5.3 \\
5.2 \\
5.5 \\
13.9 \\
14.0 \\
20.0 \\
17.3 \\
8.7 \\
15.9 \\
5.9 \\
5.5 \\
6.1 \\
6.7 \\
5.2\end{array}$ & $\begin{array}{l}26.8 \\
25.8 \\
33.1 \\
29.2 \\
25.9 \\
32.4 \\
33.9 \\
61.3 \\
75.4 \\
75.5 \\
57.9 \\
46.5 \\
87.3 \\
17.0 \\
20.2 \\
25.4 \\
22.2 \\
11.5 \\
17.5\end{array}$ & $\begin{array}{l}18.0 \\
28.8 \\
21.3 \\
20.8 \\
22.9 \\
25.6 \\
24.5 \\
49.1 \\
58.0 \\
64.2 \\
54.8 \\
56.2 \\
97.0 \\
21.9 \\
27.2 \\
37.8 \\
30.6 \\
34.2 \\
45.0\end{array}$ & $\begin{array}{l}20.8 \\
21.2 \\
19.7 \\
18.8 \\
19.8 \\
22.0 \\
19.8 \\
30.2 \\
41.4 \\
48.1 \\
37.5 \\
53.2 \\
80.9 \\
29.1 \\
28.2 \\
51.5 \\
28.6 \\
28.7 \\
52.2\end{array}$ & $\begin{array}{r}9.1 \\
18.1 \\
13.3 \\
10.4 \\
12.5 \\
11.8 \\
11.6 \\
16.2 \\
20.6 \\
17.4 \\
15.8 \\
16.5 \\
18.2 \\
15.5 \\
15.5 \\
3.9 \\
4.9 \\
5.8 \\
10.2\end{array}$ & $\begin{array}{r}3.8 \\
17.2 \\
4.8 \\
5.1 \\
5.4 \\
10.2 \\
8.2 \\
13.2 \\
13.8 \\
12.1 \\
8.5 \\
14.5 \\
34.2 \\
5.2\end{array}$ \\
\hline
\end{tabular}



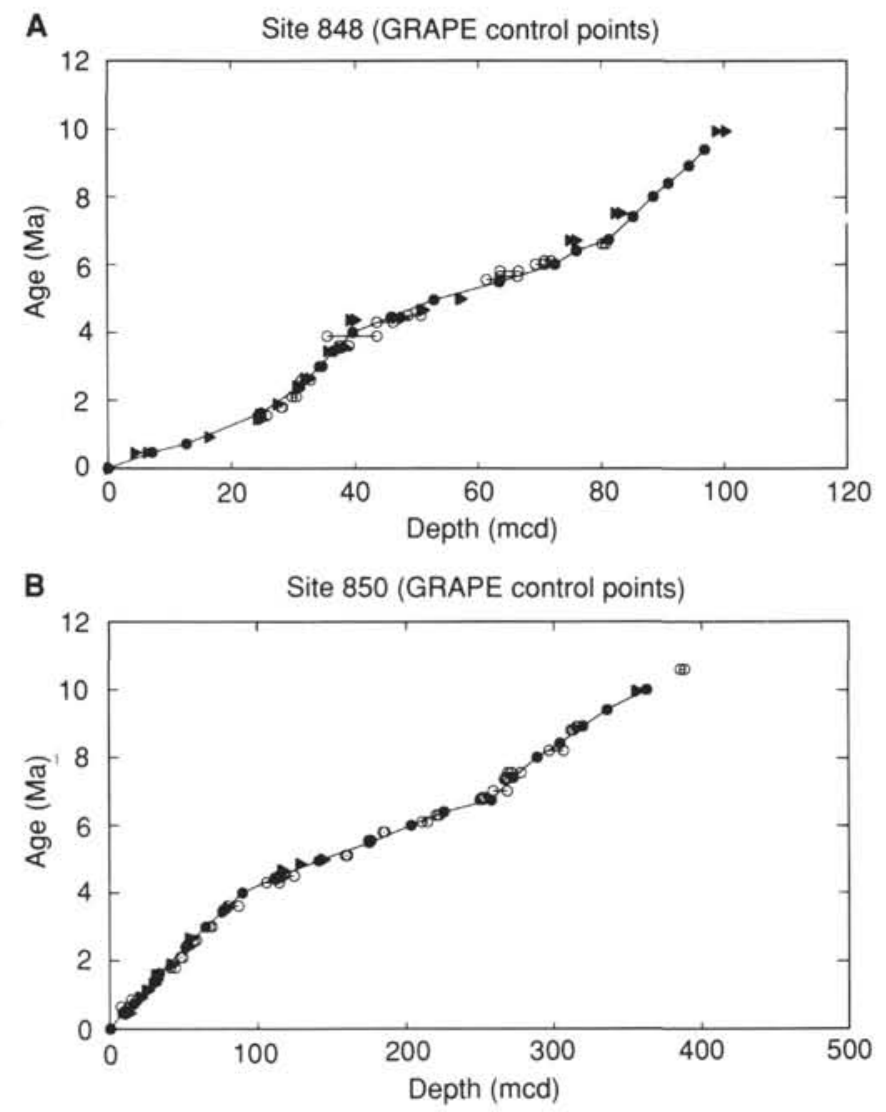

Figure 3. Plots of age vs. depth from Table 3, shown with biostratigraphic datums for selected sites. Datums are the same as those illustrated in "Biostratigraphy" section of the mentioned site chapters. A. Site 848; nannofossils = solid triangles, diatoms $=$ open circles. B. Site 850 . Solid circles represent GRAPE control points; open circles indicate diatom control points; solid triangles represent nannofossil control points.

Event $\mathrm{S}$ is a prominent density maximum at about $10 \mathrm{Ma}$, below and separated from the one associated with the top of $C$. miopelagicus. It is defined in Site 849 at $364.5 \mathrm{mcd}$, a little above the upper limit of Carpocanium cristata, and is clearly recognized in Sites 850 (363.5 $\mathrm{mcd}$ ) and 851 ( $324.7 \mathrm{mcd})$. In Site 848, the density maximum at 100 mcd has no structure and the event $S$ feature cannot be meaningfully recognized. In Site 852, event S was not reached; however, the prominent density peak dated immediately above this event, whose age may be estimated in Sites 859 and 850 as about $9.9 \mathrm{Ma}$, clearly is present at $127.5 \mathrm{mcd}$ in Hole $852 \mathrm{D}$ and was used as alternative to event $\mathrm{S}$ for determining the sedimentation rate in the lowest part of the section. The age of event $\mathrm{S}$ was estimated from Leg 138 biostratigraphy at near $10 \mathrm{Ma}$; the closest control point for this estimation is the upper limit of Coccolithus miopelagicus, and the age used for this event was $9.94 \mathrm{Ma}$, estimated at Site 845. In Site 845, the probable correlative GRAPE density event is at $160.7 \mathrm{mcd}$, where its age may be estimated as $10.04 \mathrm{Ma}$ by direct interpolation between the limits of Chron C $5-n 1$. This interpolation is between reversals separated by
$1.5 \mathrm{~m} . \mathrm{y}$. , during which time sedimentation rates probably varied; thus this is not a precise figure, and we used a rounded value of $10.0 \mathrm{Ma}$.

Table 1 presents the depths (mcd) at which the events described above have been placed in Sites 846 through 853 . These events are shown in Figure 1 (back-pocket figure). Table 2 gives sedimentation rates based on the depths and ages in Table 1 . However, these sedimentation rates are biased by the length increase in the composite sections. Ideally, these should be based on true sediment thicknesses.

Using the regressions between the mcd and mbsf scales given in Hagelberg et al. (this volume), the GRAPE records for Sites 846, 847, and 849 through 851 have been replotted in their Figure 6 (backpocket figure) on a scale that is broadly comparable to the depth scale of the downhole logs. Figure 6 of Hagelberg et al. (this volume) also shows the downhole logs for these five sites. Table 3 gives the depths on this scale at which the events were placed in the density logs. In some cases, the GRAPE density events stand out clearly; in others, the position was estimated by lining up features a few meters on either side of the event. For sites that were not logged, and for the upper unlogged portions of all sites, the depths in Table 3 have been "scaled mcd meters." These scaled mod meters were obtained using up to three linear regressions (Hagelberg et al., this volume) between the mcd and mbsf scales: one in APC sections, where the composite is generally about $15 \%$ longer than the mbsf section; one in composite XCB intervals, where the composite may be $25 \%$ longer than the mbsf section, and a 1:1 scaling in intervals that were cored a single time. Thus, this scale approximates meters below sea level and should be comparable with the log depth that is also intended to represent meters below the seafloor.

In Figure 2, we present the sedimentation rates (Table 4) of the sites using the ages of the GRAPE events (Table 1), but also using thicknesses estimated from Table 3 (i.e., log depths). It is immediately apparent that this formulation makes it much easier to compare the history of sedimentation rates of any grouping (e.g., north-south or east-west) than the presentations in the individual site chapters, each of which uses different biostratigraphic or magnetostratigraphic tiepoints for age control. When comparing this figure with those in the site chapters, one must ask whether the new control points conflict to any greater extent with the biostratigraphic information available than with the lines drawn in those chapters. Figure 3 compares original and revised plots of age vs. depth for two sites. These new age-vs.-depth lines apparently are not in conflict with the biostratigraphy to a greater extent than the age-vs.-depth lines generated in the site chapters.

\section{REFERENCES}

Arrhenius, G., 1952. Sediment cores from the East Pacific. Repts. Swedish Deep Sea Exped. 1947-48, 5:189-201.

Farrell, J., and Prell, W., 1989. Climatic change and $\mathrm{CaCO}_{3}$ preservation: an 800,000 year bathymetric reconstruction from the central equatorial $\mathrm{Pa}$ cific Ocean. Paleoceanography, 4:447-466.

Mayer, L., 1991. Extraction of high-resolution carbonate data for paleoclimate reconstruction. Nature, 352:148-151.

Vincent, E., 1981. Neogene carbonate stratigraphy of Hess Rise (Central North Pacific) and paleoceanographic implications. In Thiede, J., Vallier, T. L., et al., Init. Repts. DSDP, 62: Washington (U.S. Govt. Printing Office), 571-606.

Ms 138A-106 
Table 3. GRAPE density events from Table 1 and depths estimated for the equivalent events in the downhole density log (Hagelberg et al., this volume).

\begin{tabular}{|c|c|c|c|c|c|c|c|c|c|}
\hline Event & $\begin{array}{l}\text { Age } \\
\text { (Ma) }\end{array}$ & $\begin{array}{l}\text { Site } 846 \\
(\mathrm{mbs})^{2}\end{array}$ & $\begin{array}{l}\text { Site } 847 \\
(\mathrm{mbsf})^{4}\end{array}$ & $\begin{array}{r}\text { Site 848 } \\
(\mathrm{mbs})^{\circ}\end{array}$ & $\begin{array}{l}\text { Site } 849 \\
(\mathrm{mbs})^{2}\end{array}$ & $\begin{array}{r}\text { Site } 850 \\
(\mathrm{mbs})^{2}\end{array}$ & $\begin{array}{l}\text { Site 851 } \\
(\mathrm{mbsf})^{a}\end{array}$ & $\begin{array}{l}\text { Site } 852 \\
(m b s)^{2}\end{array}$ & $\begin{array}{l}\text { Site } 853 \\
\text { (mbsf) }\end{array}$ \\
\hline Top & 0 & 0 & 0 & 0 & 0 & 0 & 0 & 0 & 0 \\
\hline A & 0.47 & 16.7 & 13.9 & 7.4 & 11.0 & 7.5 & 8.6 & 3.7 & 1.1 \\
\hline B & 0.73 & 25.3 & 21.6 & 11.2 & 17.0 & 12.2 & 13.7 & 8.3 & 2.7 \\
\hline C & 1.63 & 53.6 & 50.0 & 22.0 & 43.2 & 31.6 & 29.2 & 19.0 & 6.4 \\
\hline D & 2.40 & 85.4 & 75.1 & 27.5 & 63.0 & 46.3 & 42.0 & 26.4 & 10.2 \\
\hline E & 2.99 & 112.7 & 92.1 & 30.2 & 76.2 & 58.4 & 52.4 & 32.9 & 13.9 \\
\hline $\bar{F}$ & 3.44 & 127.2 & 104.5 & 32.3 & 88.2 & 68.8 & 61.3 & 37.9 & 16.9 \\
\hline G & 4.00 & 143.6 & 120.5 & 35.0 & 105.9 & 82,3 & 71.1 & 43.8 & 22.8 \\
\hline H & 4.45 & 165.5 & 147.1 & 40.4 & 127.5 & 102.3 & 83.2 & 50.5 & 25.3 \\
\hline I & 4.95 & 190.1 & 171.8 & 46.8 & 157.9 & 131.5 & 98.0 & 59.7 & 30.9 \\
\hline j & 5.48 & 215.4 & 185.4 & 56.2 & 196.8 & 166.8 & 123.5 & 68.1 & 37.3 \\
\hline K & 6.00 & 223.9 & 198.1 & 64.0 & 222.0 & 196.2 & 142.0 & 75.7 & 43.0 \\
\hline L & 6.40 & 239.6 & 218.6 & 67.0 & 241.0 & 218.6 & 155.5 & 81.3 & 47.1 \\
\hline$M$ & 6.73 & 261.4 & & 71.8 & 266.4 & 250.0 & 175.7 & 87.3 & 52.4 \\
\hline $\mathrm{N}$ & 7.40 & 274.2 & & 75.3 & 278.7 & 265.5 & 188.5 & 94.1 & 62.5 \\
\hline 0 & 8.00 & 278.0 & & 78.1 & 287.2 & 283.1 & 203.6 & 105.0 & 65.9 \\
\hline P & 8.41 & 289.0 & & 80.3 & 298.4 & 297.8 & 218.6 & 106.3 & \\
\hline Q & 8.92 & 299.3 & & 83.5 & 306.5 & 312.4 & 230.8 & 109.9 & \\
\hline $\mathrm{R}$ & 9.40 & 301.8 & & 85.5 & 312.8 & 329.3 & 242.2 & 111.2 & \\
\hline$\hat{\mathrm{s}}$ & 10.00 & 306.6 & & & 321.1 & 355 & 266.9 & & \\
\hline Salt & 9.90 & & & & & & & 115.9 & \\
\hline
\end{tabular}

a'Depth below seafloor, as determined from density logs.

Table 4. Sedimentation rates based on data in Table 3.

\begin{tabular}{|c|c|c|c|c|c|c|c|c|}
\hline $\begin{array}{l}\text { Age } \\
\text { (Ma) }\end{array}$ & $\begin{array}{l}\text { Site } 846 \\
\text { Sed. rate } \\
(\mathrm{m} / \mathrm{m} . \mathrm{y} .)\end{array}$ & $\begin{array}{l}\text { Site } 847 \\
\text { Sed. rate } \\
\text { (m/m.y.) }\end{array}$ & $\begin{array}{l}\text { Site } 848 \\
\text { Sed. rate } \\
\text { (m/m.y.) }\end{array}$ & $\begin{array}{l}\text { Site } 849 \\
\text { Sed. rate } \\
(\mathrm{m} / \mathrm{m} . \mathrm{y} .)\end{array}$ & $\begin{array}{l}\text { Site } 850 \\
\text { Sed. rate } \\
(\mathrm{m} / \mathrm{m} . \mathrm{y} .)\end{array}$ & $\begin{array}{l}\text { Site } 851 \\
\text { Sed. rate } \\
(\mathrm{m} / \mathrm{m} . \mathrm{y} .)\end{array}$ & $\begin{array}{l}\text { Site } 852 \\
\text { Sed. rate } \\
(\mathrm{m} / \mathrm{m} . \mathrm{y} .)\end{array}$ & $\begin{array}{l}\text { Site } 853 \\
\text { Sed. rate } \\
(\mathrm{m} / \mathrm{m} . \mathrm{y} .)\end{array}$ \\
\hline 0.23 & 35.8 & 29.8 & 15.9 & 23.6 & 16.1 & 18.5 & 7.9 & 2.4 \\
\hline 0.60 & 32.6 & 29.2 & 14.4 & $\begin{array}{l}23.0 \\
22.7\end{array}$ & 17.8 & 19.3 & 17.4 & 6.1 \\
\hline 1.18 & 31.4 & 31.6 & 12.0 & 29.1 & 21.6 & 17.2 & 11.9 & 4.1 \\
\hline 2.02 & 41.3 & 32.6 & 7.1 & 25.7 & 19.1 & 16.6 & 9.6 & 4.9 \\
\hline 2.70 & 46.3 & 28.8 & 4.6 & 22.4 & 20.5 & 17.6 & 11.0 & 6.3 \\
\hline 3.22 & 32.2 & 27.6 & 4.7 & 26.7 & 23.1 & 19.8 & 11.1 & 6.7 \\
\hline 3.72 & 29.3 & 28.6 & 4.8 & 31.6 & 24.1 & 17.5 & 10.5 & 10.5 \\
\hline 4.23 & 48.7 & 59.1 & 12.0 & 48.0 & 44.4 & 26.9 & 14.9 & 5.6 \\
\hline 4.70 & 49.2 & 49.4 & 12.8 & 60.8 & 58.4 & 29.6 & 18.4 & 11.2 \\
\hline 5.22 & 47.7 & 25.7 & 17.7 & 73.4 & 66.6 & 48.1 & 15.8 & 12.1 \\
\hline 5.74 & 16.3 & 24.4 & 15.0 & 48.5 & 56.5 & 35.6 & 14.6 & 11.0 \\
\hline 6.20 & 39.2 & 51.2 & 7.5 & 47.5 & 56.0 & 33.7 & 14.0 & 10.2 \\
\hline 6.57 & 66.1 & & 14.5 & 77.0 & 95.2 & 61.2 & 18.2 & 16.1 \\
\hline 7.07 & 19.1 & & 5.2 & 18.4 & 23.1 & 19.1 & 10.1 & 15.1 \\
\hline 7.70 & 6.3 & & 4.7 & 14.2 & 29.3 & 25.2 & 18.2 & 5.7 \\
\hline 8.21 & 26.8 & & 5.4 & 27.3 & 35.9 & 36.6 & 3.2 & \\
\hline 8.67 & 20.2 & & 6.3 & 15.9 & 28.6 & 23.9 & 7.1 & \\
\hline 9.16 & 5.2 & & 4.2 & 13.1 & 35.2 & 23.7 & 2.7 & \\
\hline 9.70 & 8.0 & & & 13.8 & $\begin{array}{l}33.2 \\
42.8\end{array}$ & 41.2 & 9.4 & \\
\hline
\end{tabular}

